\title{
INDICATIONS OF A POSSIBLE ASSOCIATION BETWEEN PEPTIC ULCER AND VASCULAR LESIONS OF THE CENTRAL NERVOUS SYSTEM
}

\author{
BY \\ PERCY STOCKS, C.M.G., M.D., F.R.C.P. \\ Colwyn Bay, North Wales
}

Associations between two diseases may be revealed by clinical observations of their simultaneous appearance in the same community (e.g. herpes zoster and chicken pox) or of their occurrence in the same person (e.g. pernicious anaemia and subacute combined sclerosis of the spinal cord), by frequency of mention of the diseases conjointly on death certificates, or by statistical studies inspired by a suspicion that an association exists. A noteworthy example of the last-mentioned path to knowledge was the linking of rubella during pregnancy with subsequent congenital malformations in the resulting child, the first reports of which were received with incredulity.

An accidental observation of a statistical association between the geographical, environmental, or occupational distributions of two diseases could lead to the discovery of some unsuspected causative factor which they have in common, and for this reason such an observation should not be suppressed just because no explanation for it is apparent. Elucidation may be long delayed, as for example the reason for the statistical connexions between distributions of goitre and gastric cancer which were pointed out 40 years ago (Stocks, 1924, 1925).

The present paper demonstrates the existence of a strong association between death rates from gastric and duodenal ulcer on the one hand and from vascular lesions of the central nervous system on the other in 28 countries, and of a peculiar coincidence of high rates from the two causes of death in the rural districts of one part of Great Britain. Available data from mortality in different occupations and in different large towns in England and Wales are examined for common factors which might account for these findings.

Possible reasons for an association between the two causes of death which suggest themselves are:
(1) A haemorrhagic diathesis arising from some peculiarity in the blood which might be inherent in the population or acquired from their customary diet;

(2) Geographical differences in the amount of calcium ingested from the water supplies or of caffeine or other constituents derived from tea or coffee drinking;

(3) Resemblances in habits of over-eating, alcoh@ consumption, or tobacco smoking;

(4) Similar effects of differing physical activit or psychogenic stress consequent on industrialization and easier living conditions;

(5) Diagnostic peculiarities in different countries which might produce spurious correlations.

The first of these seems most likely to contain a key to the problem but, apart from some data about blood groups which are probably not relevant, I know of no comparative study of non-fatal cases of gastro-duodenal and cerebrovascular haemorrhage. Measurement of coagulability factors would have to be made in groups of such patients and in matched controls in order to investigate this. The other suggested reasons for association between the two diseases have been examined below with such statistical data as are available for the purpose.

\section{DeATH Rates in 28 Countries DURING 1960-61}

Compilations of death rates in different countries from the principal causes of death, derived from data collected by the World Health Organization and standardized to allow for differing age-distributions in the populations, have been published for the years 1950 onwards by Segi, Kurihara, and Tsukahara (1966).

In Table I (opposite) age-adjusted rates per million living of each sex are shown for 28 countries in the biennium 1960-61, for the following cause groups of 
TABLE I

MEAN ANNUAL DEATH RATES, 1960-61, ADJUSTED FOR DIFFERENCES IN AGE-DISTRIBUTION, PER MILLION LIVING IN 28 COUNTRIES, BY SEX.

\begin{tabular}{|c|c|c|c|c|c|c|c|c|c|c|}
\hline \multirow{2}{*}{ Country } & \multicolumn{2}{|c|}{ Peptic Ulcer } & \multicolumn{2}{|c|}{$\begin{array}{c}\text { Vascular } \\
\text { Lesions CNS }\end{array}$} & \multicolumn{2}{|c|}{$\begin{array}{l}\text { Cirrhosis } \\
\text { of Liver }\end{array}$} & \multicolumn{2}{|c|}{$\begin{array}{c}\text { Hypertensive } \\
\text { Heart, etc. }\end{array}$} & \multicolumn{2}{|c|}{$\begin{array}{l}\text { All Causes of } \\
\text { Death }\end{array}$} \\
\hline & $\mathbf{M}$ & $\mathbf{F}$ & $\mathbf{M}$ & $\mathbf{F}$ & $\mathbf{M}$ & $\mathbf{F}$ & $\mathbf{M}$ & $\mathbf{F}$ & $\mathbf{M}$ & $\mathbf{F}$ \\
\hline $\begin{array}{l}\text { Japan } \\
\text { Portugal } \\
\text { West Berlin } \\
\text { Scotland } \\
\text { England and Wales } \\
\text { South Africa } \\
\text { Northern Ireland } \\
\text { Austria } \\
\text { Italy } \\
\text { Australia } \\
\text { Ireland (Eire) } \\
\text { U.S.A. (all) } \\
\text { Finland } \\
\text { Greece } \\
\text { New Zealand } \\
\text { Hungary } \\
\text { Germany, West } \\
\text { Canada } \\
\text { Sweden } \\
\text { Switzerland } \\
\text { Denmark } \\
\text { Belgium } \\
\text { Netherlands } \\
\text { Israel } \\
\text { Czechoslovakia } \\
\text { Venezuela } \\
\text { France } \\
\text { Norway }\end{array}$ & $\begin{array}{r}199 \\
155 \\
129 \\
129 \\
100 \\
98 \\
98 \\
94 \\
92 \\
87 \\
83 \\
81 \\
80 \\
79 \\
77 \\
76 \\
73 \\
72 \\
69 \\
62 \\
61 \\
61 \\
60 \\
57 \\
56 \\
42 \\
37 \\
37\end{array}$ & $\begin{array}{l}72 \\
32 \\
38 \\
35 \\
32 \\
27 \\
32 \\
31 \\
16 \\
28 \\
29 \\
24 \\
24 \\
21 \\
31 \\
20 \\
15 \\
21 \\
27 \\
25 \\
27 \\
13 \\
18 \\
15 \\
16 \\
18 \\
8 \\
15\end{array}$ & $\begin{array}{r}2,267 \\
1,354 \\
1,108 \\
1,300 \\
1,008 \\
889 \\
1,057 \\
1,127 \\
1,105 \\
957 \\
843 \\
867 \\
1,116 \\
907 \\
803 \\
1,111 \\
1,198 \\
764 \\
770 \\
802 \\
752 \\
496 \\
697 \\
707 \\
798 \\
510 \\
907 \\
917\end{array}$ & $\begin{array}{r}1,594 \\
1,131 \\
950 \\
1,200 \\
920 \\
960 \\
1,105 \\
972 \\
869 \\
951 \\
929 \\
785 \\
1,129 \\
663 \\
906 \\
1,055 \\
1,065 \\
757 \\
773 \\
739 \\
743 \\
406 \\
736 \\
819 \\
682 \\
484 \\
671 \\
897\end{array}$ & $\begin{array}{r}152 \\
292 \\
259 \\
41 \\
24 \\
85 \\
27 \\
252 \\
223 \\
55 \\
23 \\
136 \\
46 \\
157 \\
21 \\
90 \\
187 \\
78 \\
46 \\
153 \\
54 \\
85 \\
37 \\
66 \\
94 \\
171 \\
319 \\
32\end{array}$ & $\begin{array}{r}76 \\
123 \\
95 \\
25 \\
16 \\
40 \\
19 \\
71 \\
73 \\
29 \\
12 \\
66 \\
21 \\
53 \\
17 \\
44 \\
177 \\
41 \\
28 \\
33 \\
60 \\
38 \\
24 \\
35 \\
47 \\
76 \\
132 \\
22\end{array}$ & $\begin{array}{r}220 \\
215 \\
97 \\
310 \\
247 \\
230 \\
232 \\
114 \\
230 \\
213 \\
220 \\
340 \\
199 \\
89 \\
154 \\
156 \\
106 \\
194 \\
160 \\
179 \\
92 \\
175 \\
89 \\
132 \\
267 \\
285 \\
63 \\
120\end{array}$ & $\begin{array}{l}176 \\
192 \\
112 \\
216 \\
204 \\
243 \\
247 \\
150 \\
236 \\
210 \\
238 \\
350 \\
393 \\
93 \\
181 \\
195 \\
136 \\
218 \\
192 \\
232 \\
116 \\
210 \\
128 \\
157 \\
271 \\
258 \\
55 \\
140\end{array}$ & $\begin{array}{r}9,965 \\
11,961 \\
10,075 \\
10,557 \\
9,364 \\
10,796 \\
9,750 \\
10,213 \\
9,069 \\
9,212 \\
9,258 \\
9,550 \\
10,621 \\
7,232 \\
8,885 \\
9,326 \\
9,683 \\
8,726 \\
9,750 \\
8,394 \\
7,546 \\
9,546 \\
7,064 \\
7,134 \\
8,990 \\
11,653 \\
9,100 \\
7,216\end{array}$ & $\begin{array}{l}7,062 \\
8,825 \\
6,564 \\
7,082 \\
6,005 \\
6,925 \\
6,950 \\
6,729 \\
6,414 \\
5,843 \\
7,161 \\
6,140 \\
6,866 \\
5,701 \\
6,120 \\
6,955 \\
6,662 \\
5,858 \\
5,448 \\
5,743 \\
5,794 \\
6,283 \\
5,209 \\
5,962 \\
6,140 \\
9,678 \\
5,571 \\
5,170\end{array}$ \\
\hline
\end{tabular}

Notes: Countries ranked in descending order of peptic ulcer rates for males. U.S.A. rates are for "white" and "non-white" combined. "CNS" means "affecting the central nervous system".

the Intermediate List of the International Classification of Diseases and Causes of Death:

Gastric and duodenal ulcer (B 33), hypertensive heart, hypertension (B 28, 29), vascular lesions of the central nervous system (B 22), cirrhosis of the liver (B 37), and all causes.

The correlations between the first and third of these (designated as "peptic ulcer" and "stroke" for brevity in the rest of this paper) are shown in Table II.

TABLE II

CORRELATIONS BETWEEN CAUSES OF DEATH IN 28 COUNTRIES

\begin{tabular}{|c|c|c|c|c|}
\hline \multirow{2}{*}{ Cause of Death } & \multicolumn{2}{|c|}{ Peptic Ulcer } & \multicolumn{2}{|c|}{$\begin{array}{l}\text { Cerebrovascular } \\
\text { Lesions }\end{array}$} \\
\hline & Males & Females & Males & Females \\
\hline $\begin{array}{l}\text { Peptic ulcer } \\
\text { Hypertensive heart, etc. } \\
\text { Cirrhosis of liver } \\
\text { All causes }\end{array}$ & $\begin{array}{r}-\overline{0} \\
+0.330 \\
+0.190 \\
+0.494\end{array}$ & $\begin{array}{l}-\overline{0.065} \\
+0.136 \\
+0.243\end{array}$ & $\begin{array}{l}+0 \cdot 848 \\
+0 \cdot 124 \\
+0 \cdot 283 \\
+0 \cdot 314\end{array}$ & $\begin{array}{l}+0.757 \\
-0.149 \\
+0.009 \\
+0.235\end{array}$ \\
\hline
\end{tabular}

Coefficients below 0.3 may be disregarded, but those for males between peptic ulcer and hypertensive disease and between stroke and cirrhosis of the liver are of possible significance. The correlations for each sex between peptic ulcer and stroke are highly significant, and this remains true when the correlations with all causes are held constant (partial coefficients 0.849 for males and 0.735 for females).
It has been suggested that in Japan, at any rate in the rural areas, there is a tendency to certify a cerebrovascular lesion as the cause of some sudden deaths which might have been due to coronary disease, and it is certainly true that the death rate from the latter appears to be remarkably low whereas that for cerebrovascular lesions is very high. This question has been thoroughly discussed by Robb-Smith (1967). It may well be that the age-adjusted death rates for stroke in Table $I$ are overstated, and the possible effect of this on the correlations in Table II must be kept in mind. The high rates for both peptic ulcer and stroke in Japan influence the coefficient of course, but the remaining 27 countries still produce a coefficient of 0.78 for males.

The countries where age-adjusted rates exceeded the respective means for all the 28 countries both for peptic ulcer and cerebrovascular lesions were Japan, Scotland, England and Wales, Northern Ireland, West Berlin, Austria, and Portugal for each sex, with the addition of Italy for males only and of Ireland, Australia, New Zealand, and South Africa for females only. In 23 countries where data were available, the total fuel energy consumed per head of population gave for males insignificant correlations of $\mathbf{0 . 2}$ with both peptic ulcer and stroke, whilst cigarette consumption per adult gave coefficients under $0 \cdot 1$, indicating that neither 
industrial development nor smoking habits were factors contributing appreciably to the association between the two diseases.

Although an excessive consumption of refined sugar in Western countries has been postulated as a factor in the causation of peptic ulcer (Cleave, 1962), little attention seems to have been paid to possible effects of tea and coffee. Since these beverages are drunk in widely different quantities in different countries, and with great variations in the customary addition of sugar and milk, it seemed worthwhile to examine the national death rates from peptic ulcer and cerebrovascular lesions in relation to consumption of tea and coffee per person per annum as estimated from the amounts imported. For this purpose the number of metric tons which were imported into twenty countries during 1965 and 1966, details of which were extracted from tabulations made by the United Nations Organization $(1965,1966)$, have been converted in Table III to numbers of pounds per head of population. In Japan, where tea is grown, this cannot be evaluated, but it is assumed to be above the average for the other nineteen countries ( $2 \mathrm{lb}$. per head).

The countries are ranked in Table III according to the rate of consumption, ranging for tea from 8.8 to $0.02 \mathrm{lb}$. and for coffee from 28.3 to $0.4 \mathrm{lb}$. per person, the mean values for all countries being indicated by the broken lines at $2 \cdot 2$ and $10 \cdot 3 \mathrm{lb}$. respectively. The measures of mortality used in the Table are the mean annual age-adjusted death rates per million males or females in 1960-61 shown in Table I, the plus sign indicating a rate above the mean for the twenty countries, that is, 82.8 and
25.6 for the two sexes for peptic ulcer, and 980 and 905 for cerebrovascular lesions.

Tea.-The six countries using more than $2 \mathrm{lb}$. of tea per person comprised Japan and five countries in the British Commonwealth and every one had high death rates from peptic ulcer among females whereas none of the other fourteen countries had rates above the average. The correlation between peptic ulcer mortality and tea consumption was +0.479 . The correspondence was not quite so notable among males, five of the six countries with tea consumption over $2 \mathrm{lb}$. having high ulcer death rates compared with only one (Italy) of the other fourteen countries, the correlation being $+0 \cdot 168$ (not significant).

Cerebrovascular lesions with high death rates occurred in two groups of countries, those with tea consumption exceeding $2 \mathrm{lb}$. per person and those with $0.4 \mathrm{lb}$. or less, this being particularly evident for females, as the Table shows. The correlation for this sex was positive though not significant $(+0 \cdot 201)$, but for males it was slightly negative. No explanation is apparent for the curious relationship between the two diseases and the amount oB tea consumption, but the fact that the correlations were positive for each disease among females might contribute something to the interrelation between the two diseases observed in the 28 countries in Table I.

Coffee.-Consumption is related in a negative sense with mortality from each disease, the correlations with peptic ulcer being -0.31 for males and

TABLE III

TEA AND COFFEE CONSUMPTION IN TWENTY COUNTRIES IN ASSOCIATION WITH OVER-AVERAGE RATES FOR PEPTIC ULCER AND STROKE, BY SEX

\begin{tabular}{|c|c|c|c|c|c|c|c|c|c|c|c|}
\hline \multirow{2}{*}{\multicolumn{2}{|c|}{$\begin{array}{c}\text { Tea } \\
\text { (Mean 2.2 lb. per person) }\end{array}$}} & \multicolumn{2}{|c|}{ Ulcer } & \multicolumn{2}{|c|}{ Stroke } & \multirow{2}{*}{\multicolumn{2}{|c|}{$\begin{array}{c}\text { Coffee } \\
\text { (Mean } 10 \cdot 3 \mathrm{lb} \text {. per person) }\end{array}$}} & \multicolumn{2}{|c|}{ Ulcer } & \multicolumn{2}{|c|}{ Stroke } \\
\hline & & $\mathbf{M}$ & $\mathbf{F}$ & $\mathbf{M}$ & $\mathbf{F}$ & & & $\mathbf{M}$ & $\mathbf{F}$ & $\mathbf{M}$ & $\mathbf{F}$ \\
\hline $\begin{array}{l}\text { United Kingdom } \\
\text { Ireland } \\
\text { New Zealand } \\
\text { Australia } \\
\text { Canada } \\
\text { Japan }\end{array}$ & $\begin{array}{l}8 \cdot 8 \\
8 \cdot 5 \\
6 \cdot 7 \\
4 \cdot 6 \\
2 \cdot 2 \\
>2\end{array}$ & $\begin{array}{l}+ \\
+ \\
+ \\
+ \\
+\end{array}$ & $\begin{array}{l}+ \\
+ \\
+ \\
+ \\
+ \\
+\end{array}$ & $\begin{array}{l}+ \\
+ \\
+\end{array}$ & $\begin{array}{l}+ \\
+ \\
+ \\
+ \\
+\end{array}$ & $\begin{array}{l}\text { Sweden } \\
\text { Denmark } \\
\text { Finland } \\
\text { Norway } \\
\text { Switzerland } \\
\text { Netherlands }\end{array}$ & $\begin{array}{l}28 \cdot 3 \\
25 \cdot 4 \\
22 \cdot 3 \\
21 \cdot 1 \\
15 \cdot 6 \\
15 \cdot 6\end{array}$ & & + & + & + \\
\hline $\begin{array}{l}\text { Netherlands } \\
\text { Israel } \\
\text { France }\end{array}$ & $\begin{array}{l}1 \cdot 8 \\
1 \cdot 4 \\
1 \cdot 2\end{array}$ & & & & & France & $\begin{array}{l}10 \cdot 8 \\
10 \cdot 7\end{array}$ & & & + & + \\
\hline $\begin{array}{l}\text { U.S.A. } \\
\text { Denmark } \\
\text { Switzerland } \\
\text { Sweden } \\
\text { Finland } \\
\text { Germany, W. } \\
\text { Norway } \\
\text { Austria } \\
\text { Italy } \\
\text { Greece } \\
\text { Portugal }\end{array}$ & $\begin{array}{l}0 \cdot 73 \\
0 \cdot 70 \\
0 \cdot 50 \\
0 \cdot 46 \\
0 \cdot 40 \\
0 \cdot 33 \\
0 \cdot 29 \\
0 \cdot 24 \\
0 \cdot 10 \\
0 \cdot 03 \\
0 \cdot 02\end{array}$ & + & & $\begin{array}{l}+ \\
+ \\
+ \\
+ \\
+ \\
+\end{array}$ & $\begin{array}{l}+ \\
+ \\
+ \\
+ \\
+ \\
+\end{array}$ & $\begin{array}{l}\text { Canada } \\
\text { Austria } \\
\text { Israel } \\
\text { Italy } \\
\text { United Kingdom } \\
\text { Portugal } \\
\text { Australia } \\
\text { New Zealand } \\
\text { Greece } \\
\text { Japan } \\
\text { Ireland }\end{array}$ & $\begin{array}{l}8 \cdot 6 \\
6 \cdot 2 \\
5 \cdot 5 \\
5 \cdot 3 \\
3 \cdot 5 \\
3 \cdot 3 \\
2 \cdot 9 \\
2 \cdot 8 \\
2 \cdot 8 \\
1 \cdot 1 \\
0 \cdot 4\end{array}$ & $\begin{array}{l}+ \\
+ \\
+ \\
+ \\
+ \\
+\end{array}$ & $\begin{array}{l}+ \\
+ \\
+ \\
+ \\
+ \\
+\end{array}$ & $\begin{array}{l}+ \\
+ \\
+ \\
+\end{array}$ & $\begin{array}{l}+ \\
+ \\
+ \\
+ \\
+ \\
+ \\
+\end{array}$ \\
\hline
\end{tabular}


-0.50 for females, and with stroke -0.50 for males and -0.31 for females. The Scandinavian countries used over $20 \mathrm{lb}$. per person, but their mean rates for peptic ulcer were below the general average in each sex and only Finland had high rates for stroke. The Commonwealth countries and Japan used less than $4 \mathrm{lb}$. per person but had consistently high rates for females for both diseases. There were seven countries with coincident high rates for this sex, however, and this again might contribute towards the interrelation between the diseases seen in Table I.

Death Rates in Rural Parts of Counties of GREAT BRITAIN

The National Atlas of Disease Mortality in the United Kingdom (Howe, 1963) shows in a series of maps the standardized mortality ratios for each sex in 1954-58 in the rural and urban parts of counties. From these can be deduced the geographical distribution of mortality from peptic ulcer and stroke in rural districts. Counties having small populations in such districts have been combined with adjacent counties in the three countries. The mean values of the standardized mortality ratios, which are based on the United Kingdom mortality for the sex in question taken as 100 , differed considerably in the three countries as shown below:

\begin{tabular}{l|c|c|c|c|c}
\hline \multirow{2}{*}{ Country } & \multirow{2}{*}{$\begin{array}{c}\text { Units of } \\
\text { Area }\end{array}$} & \multicolumn{2}{|c|}{ Peptic Ulcer } & \multicolumn{2}{|c}{ Stroke } \\
\cline { 3 - 6 } & & Males & Females & Males & Females \\
\hline Scotland & 24 & 103 & 103 & 118 & 135 \\
England & 40 & 80 & 97 & 100 & 99 \\
Wales & 8 & 80 & 66 & 115 & 133 \\
\hline
\end{tabular}

In Scotland the distributions of the two diseases in the rural units were correlated to the extent of +0.48 for males and +0.15 for females, the male coefficient being statistically significant.

For males there were twelve units where mortality exceeded the Scottish mean for both diseases and all of these except Zetland formed a compact southern area contingent with Northumberland and Durham in England, which also showed high rates for both, as shown in the Map. The eleven Scottish areas were Argyll-Bute, Ayr, Berwick-East, Lothian, Dumfries, Dumbarton, Fife, Kirkcudbright, PeeblesRoxburgh-Selkirk, Renfrew, Stirling, and Wigtown. The only other areas of England and Wales with a coincidence of high rates for males were Derby, Essex, Hertford, Worcester, Denbigh-Flint, and Glamorgan.
For females the Scottish units showing an excess for both diseases formed a smaller southern area comprising Argyll-Bute, Ayr, Lanark, Midlothian, Clackmannan-Kinross, Fife, and Berwick-East Lothian, and in addition to Durham there was a continuous area of northern England, comprising the West Riding, Lancashire, and Derby, and extending to Leicester. Peptic ulcer rates in isolated counties are unreliable owing to the small numbers of deaths, and the Map is for males only.

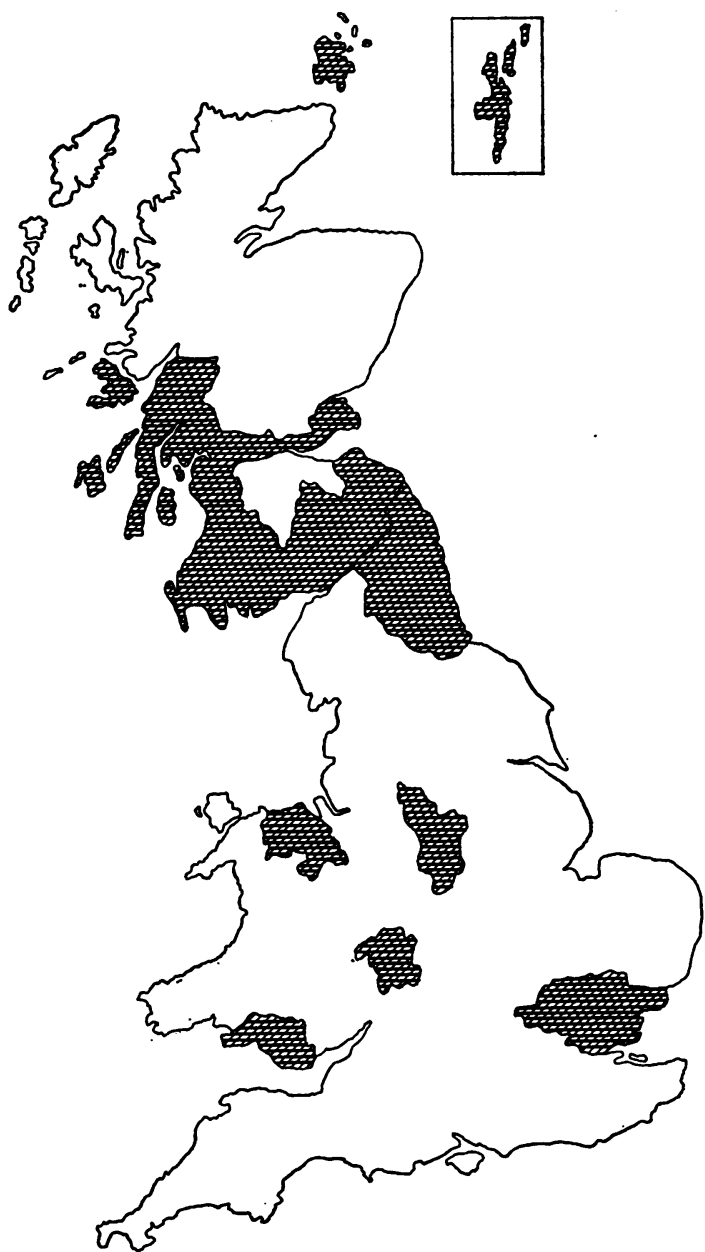

FIGURE.-Map of Great Britain, showing rural areas in which standardized mortality rates of males during 1952-56 exceeded the country average for both peptic ulcer and cerebrovascular lesions.

The curious distribution of coincident high mortality shown by the Map suggests that some causative factor or factors affecting the incidence of both diseases may be present in the rural districts 
of southern Scotland and parts of northern England, and also perhaps in the other scattered areas. The nature of these remains unknown, but peptic ulcer incidence is affected by the distribution of blood groups, and it might be of some significance that in the population of southern Scotland, northernmost England, and part of North Wales, the frequency ratio between blood groups $A$ and $O$ is about 0.3 , compared with 0.4 in the rest of England and Wales and $\mathbf{0 . 2}$ in northern Scotland, as indicated by the maps prepared by Mourant and Watkin (1952).

\section{Mortality of Men in Different Occupations}

In the Registrar General's report on Occupational Mortality in England and Wales during 1949-1953 (1958), standardized mortality ratios (SMRs) at ages 20 to 64 years were given for men in 110 occupation groups. In Table 3A(1) of Part II, Vol. 2, the actual and expected deaths at ages 20 to 64 from gastric ulcer (540) and duodenal ulcer (541) were shown separately, so combined SMRs for peptic ulcer (540-541) were obtained by dividing the actual by the expected numbers and multiplying by 100 . For cerebrovascular lesions (330-334), the SMRs were given in the Table. Seventeen occupational groups yielding fewer than ten deaths from each of the causes in question were excluded, since their rates would be subject to large random errors. This left 93 groups, of which six could not be classified as to physical activity, but the remaining 87 groups were divided into four categories of activity according to the nature of the work involved:

A. Hard physical work

B. Moderate activity (standing, walking, etc.)

C. Partly sedentary work

D. Mainly sedentary work

U. Activity indeterminate

The average SMRs of the 87 classified occupations were 102 for peptic ulcer and 103 for "stroke"; values equal to or exceeding these have been $\frac{\vec{\alpha}}{\mathrm{C}}$ designated "high", and values below them have been? designated "low" for purposes of this study. The $\vec{F}$ " numbers of occupations in each category and the average SMRs are shown in Table IV.

TABLE IV

OCCUPATIONS CLASSIFIED BY PHYSICAL ACTIVITY

\begin{tabular}{|c|c|c|c|c|c|c|c|}
\hline \multicolumn{2}{|l|}{ Activity } & $\mathbf{A}$ & B & C & D & $\begin{array}{l}\text { Total } \\
\text { A to D }\end{array}$ & $\mathbf{U}$ \\
\hline \multicolumn{2}{|c|}{ No. of Occupations } & 27 & 30 & 16 & 14 & 87 & 6 \\
\hline Average SMRs & $\begin{array}{l}\text { Peptic ulcer } \\
\text { "Stroke" }\end{array}$ & $\begin{array}{r}101 \\
91\end{array}$ & $\begin{array}{l}111 \\
110\end{array}$ & $\begin{array}{r}94 \\
110 \\
\end{array}$ & $\begin{array}{r}87 \\
104\end{array}$ & $\begin{array}{l}102 \\
103\end{array}$ & $\begin{array}{l}(326) \\
(289)\end{array}$ \\
\hline
\end{tabular}

The averages for the indeterminate group (U) were very high because three of the occupations comprised retired men from the Services. Mortality from peptic ulcer was lowest in sedentary occupations, whereas that from stroke was lowest in 응 occupations entailing hard physical work. Moderate $\stackrel{\mathbb{Q}}{\stackrel{9}{-}}$ activity (B) appeared to be unfavourable for bo $\vec{\varphi}$ diseases.

Table $\mathrm{V}$ analyses the occupations separate according to their activity category and wheth their mortalities from the two causes were high or low. Out of the 87 in categories A to D, 54 showed coincident high or low rates from peptic ulcer and stroke, compared with 44.6 expected if there had been no association, a significant excess of coincidences $\left(\chi^{2}=4 \cdot 7 ; P=0 \cdot 03\right)$. If the six occupations with indeterminate activity are included, there were sixty out of 93 with coincident high or low rates and the association is even stronger $\left(\chi^{2}=8 \cdot 2 ; P=0 \cdot 007\right)$.

The 21 occupations in groups $A$ to $D$ with high rates from both diseases are detailed opposite since they may suggest some clue to the reasons for the association:

TABLE V

OCCUPATIONS OF MEN AGED 20 TO 64 IN ENGLAND AND WALES, 1949-53, CLASSIFIED BY MORTALITY LEVELS FOR PEPTIC ULCER AND STROKE AND DIVIDED INTO CATEGORIES OF PHYSICAL ACTIVITY

\begin{tabular}{|c|c|c|c|c|c|c|c|c|c|c|}
\hline \multirow{3}{*}{$\begin{array}{l}\text { Peptic } \\
\text { Ulcer }\end{array}$} & \multirow{3}{*}{ Stroke } & \multicolumn{4}{|c|}{$\begin{array}{l}\text { No. of Occupations in } \\
\text { Activity Categories }\end{array}$} & \multicolumn{2}{|c|}{ Totals (A to D) } & \multicolumn{3}{|c|}{ Including Indeterminate } \\
\hline & & \multirow{2}{*}{$\mathbf{A}$} & \multirow{2}{*}{ B } & \multirow{2}{*}{$\mathbf{C}$} & \multirow{2}{*}{$\mathbf{D}$} & \multirow{2}{*}{ Actual } & \multirow{2}{*}{ Expected } & \multirow{2}{*}{$\mathbf{U}$} & \multicolumn{2}{|c|}{ Total with A to D } \\
\hline & & & & & & & & & Actual & Expected \\
\hline $\begin{array}{l}\text { High } \\
\text { High } \\
\text { Low } \\
\text { Low }\end{array}$ & $\begin{array}{l}\text { High } \\
\text { Low } \\
\text { High } \\
\text { Low }\end{array}$ & $\begin{array}{r}4 \\
8 \\
2 \\
13\end{array}$ & $\begin{array}{r}11 \\
6 \\
5 \\
8\end{array}$ & $\begin{array}{l}3 \\
2 \\
4 \\
7\end{array}$ & $\begin{array}{l}3 \\
1 \\
5 \\
5\end{array}$ & $\begin{array}{l}21 \\
17 \\
16 \\
33\end{array}$ & $\begin{array}{l}15 \cdot 3 \\
22 \cdot 7 \\
19 \cdot 7 \\
29 \cdot 3\end{array}$ & $\frac{5}{1}$ & $\begin{array}{l}26 \\
17 \\
16 \\
34\end{array}$ & $\begin{array}{l}18 \cdot 5 \\
24 \cdot 5 \\
21 \cdot 5 \\
18 \cdot 5\end{array}$ \\
\hline \multicolumn{2}{|c|}{ Totals } & 27 & 30 & 16 & 14 & 87 & $87 \cdot 0$ & 6 & 93 & $93 \cdot 0$ \\
\hline
\end{tabular}




\section{OCCupations With High SMRS fOR BOth Diseases}

\begin{tabular}{lll}
\hline A. & 17 & Moulders, coremakers \\
A. & 21 & Smiths, forgers \\
A. & 22 & Platers \\
A. & 58 & $\begin{array}{l}\text { Builders, bricklayers', plasterers', masons' } \\
\text { labourers }\end{array}$
\end{tabular}

B. 26 Machine erectors, maintenance engineers, motor mechanics, fitters

B. 37 Oxyacetylene and electric welders

B. 40 Openers, sorters, blenders, carders (textiles)

B. 43 Weavers-cotton

B. 47 Boot and shoe-makers (factory)

B. 79 Proprietors, retail-greengrocery, meat, fish, poultry

B. 101 Police - other ranks

B. 103 Barmen

B. 104 Waiters, still-room hands

B. 105 Barbers, hairdressers, manicurists

B. 106 Domestic servants-indoor

\begin{tabular}{lrl}
\hline C. & 33 & Electrical fitters \\
C. & 64 & French polishers \\
C. & 102 & Publicans, owners of hotels and inns \\
\hline D. & 49 & Garment makers \\
D. & 50 & Tailors \\
D. & 109 & $\begin{array}{l}\text { Drivers of stationary engines and cranes, civil } \\
\end{array}$ \\
& engineering plant workers
\end{tabular}

To these may be added five whose activity was indeterminate: 53, makers of alcoholic drinks; 94, army officers-retired; 95, other ranks of army-active; 96, other ranks of army-retired; 98, naval ratingsretired.

Out of the total of 26 occupations with coincident high rates, there were twelve in which the SMR from cirrhosis of the liver was 102 or over (Nos 17, $33,53,58,79,94,95,96,98,102,103,106)$ whereás in the remaining 67 occupations there were only fourteen (Nos 1, 45, 52, 55, 57, 67, 72, 75, 76, 81,
89, 110). The high significance of this $\left(\chi^{2}=18 \cdot 7\right.$; $\mathbf{P}<0.001)$ suggests that addiction to alcohol is one common factor in the causation of the two diseases.

\section{SUMMARY}

Standardized death rates from peptic ulcer and from vascular lesions of the central nervous system show a strong association between the one and the other in each sex when 28 countries are compared, and there is a peculiar coincidence of high rates throughout the rural districts of southern Scotland.

In 93 occupations of men aged 20 to 64 years in England and Wales, the occurrence of coincident high and low rates from the two diseases in 1949-53 was associated significantly with the physical activity required by the work, and also with mortality from cirrhosis of the liver.

\section{REFERENCES}

Cleave, T. L. (1962). "Peptic Ulcer". Wright, Bristol.

Howe, G. M. (1963). "National Areas of Disease Mortality in the United Kingdom". Royal Geographical Society. Nelson, London.

Mourant, A. E., and Watkin, I. M. (1952). Heredity, 6, 13 (Blood groups, anthropology, and language in Wales and the Western countries).

Registrar General (1958). "Decennial Supplement, England and Wales, 1951. Occupational Mortality", Part II, Vol. 2: Tables. H.M.S.O., London.

Robb-Smith, A. H. T. (1967). "The Enigma of Coronary Heart Disease". Lloyd-Luke, London.

Stocks, P. (1924). Biometrika, 16, 364 (Cancer and goitre).

(1925). Ibid., 17, 159 (Some further notes on cancer and goitre distribution).

United Nations (1967). "Commodity Trade Statistics", vol. 15, 1965; vol. 16, 1966. Statistical Papers, Series D. U.N.O., New York.

Segi, M., Kurihara, M., and Tsukahara, Y. (1966). "Mortality from Selected Causes in Thirty Countries (1950-61)". Tohoku University School of Medicine, Sendai, Japan. Kyokai, Tokio. 